\title{
Genetic Variability, Heritability and Genetic Advance Study for Seed Yield and Yield Component Traits in a Chickpea Recombinant Inbred Line (RIL) Population
}

\author{
Priyanka Joshi $^{1,2^{*}}$, Mohammad Yasin ${ }^{1}$ and Prity Sundaram ${ }^{2,3}$ \\ ${ }^{1}$ RVSKVV, RAK College of Agriculture, Sehore - 466001 (M.P.), India \\ ${ }^{2}$ International Crops Research Institute for the Semi-Arid Tropics, Hyderabad, India \\ ${ }^{3}$ Bihar Agricultural University, Sabour, Bhagalpur - 813210, Bihar, India \\ *Corresponding Author E-mail: priyanka.joshi95@yahoo.com \\ Received: 6.02.2018 | Revised: 10.03.2018 | Accepted: 14.03.2018
}

\begin{abstract}
Experimental material consisted 252 intra-specific recombinant inbred line (RIL) population derived from a cross between desi (ICC 283) and kabuli (ICC 8261) type of chickpea, received from ICRISAT, Patancheru, India. Experiment was conducted at Rafi Ahmed Kidwai College of Agriculture, Sehore, Bhopal, India, during rabi 2011-12 and 2012-13. Traits assessed were days to 50\% flowering, maturity, plant height, biological yield, seed yield, harvest index and 100-seed weight. Standard statistical analysis was adopted for calculating the genetic variability, heritability and genetic advance. Out of seven characters studied biological yield, seed yield, harvest index and 100-seed weight exhibited high genotypic coefficient of variation and heritability coupled with high genetic advance as percent of mean which revealed that these traits might be under control of additive gene effects and therefore these traits are more reliable for effective selection for developing desirable lines.
\end{abstract}

Key words: Chickpea, RILs, Yield traits, Genetic variability and Heritability

\section{INTRODUCTION}

Chickpea is the second most important pulse crop in the world after dry beans. Crop domestication under the influence of evolutionary forces and human derived selection process has resulted in several desirable traits in crops such as high productivity, short duration, reduced seed dispersal/ dormancy and branching, uniform flowering/ fruiting and seed maturation ${ }^{1,2,3,4}$. The extent of variability for various quantitative traits including seed yield available to breeders determine the success that can be achieved through genetic improvement. The observed variability may be grouped under heritable and non-heritable components with the help of suitable parameters like genotypic coefficient of variation (GCV), phenotypic coefficient of variation $(\mathrm{PCV})$, heritability and genetic advance.

Cite this article: Joshi, P., Yasin, M. and Sundaram, P., Genetic Variability, Heritability and Genetic Advance Study for Seed Yield and Yield Component Traits in a Chickpea Recombinant Inbred Line (RIL) Population, Int. J. Pure App. Biosci. 6(2): 136-141 (2018). doi: http://dx.doi.org/10.18782/2320-7051.6231 
Assessment of genetic variability for yield and its contributing traits in recombinant inbred line (RIL) was an important purpose for screening of suitable and diverse RILs. Phenotype of an individual reflects the genotypic constitution and its interaction with the environment. Phenotypic and genotypic coefficient of variations play an important role in understanding the extent and nature of genetic variability present in a population derived from two diverse parents in chickpea. The populations derived from crossing genetically diverse parental sources generate substantial variability that can be harnessed by plant breeders through selection. The present investigation was undertaken using a chickpea RIL population comprising 252 lines developed using two highly diverse genotypes belonging to diverse groups viz., desi (ICC 283) and kabuli (ICC 8261) to identify desirable lines having better trait combinations that can be used in chickpea improvement.

\section{MATERIAL AND METHODS}

The present investigation was carried out at research experimental field of Rafi Ahmed Kidwai College of Agriculture, Sehore (Madhya Pradesh) during rabi 2011-12 and 2012-13. Experimental material consisted 252 intra-specific RIL of chickpea and two parents i.e. ICC 283 (Desi) and ICC 8261 (Kabuli) which were received from International Crops Research Institute for the Semi-Arid Tropics, Patancheru (Telangana), India. A set of 252 RILs' population and parents were grown in a randomized block design with two replications during rabi 2011-12 and 2012-13. Each entry was sown in $4 \mathrm{~m}$ long row with $30 \mathrm{~cm}$ row-torow and $10 \mathrm{~cm}$ plant-to-plant spacing. The fertilizer dose of 20:50:0:20 NPKS $\mathrm{kg} / \mathrm{ha}$ was applied as basal dose. Recommended package of practices were adopted for optimum crop growth and plant protection under both conditions. Data on seven quantitative traits viz., days to $50 \%$ flowering, days to physiological maturity, plant height $(\mathrm{cm})$, biological yield per plant $(\mathrm{g})$, seed yield per plant (g), harvest indexper plant (\%) and hundred seed weight $(\mathrm{g})$ were recorded. The sample size for experiment was five plants from each line. Standard procedures were adopted for statistical analysis and their interpretation. Statistical analysis included genotypic coefficient of variation $(\mathrm{GCV})^{5}$, phenotypic coefficient of variation $(\mathrm{PCV})^{5}$, broad sense heritability ${ }^{6}$, genetic advance $(\mathrm{GA})^{7}$ and genetic advance as percent of mean $(\mathrm{GAM})^{7}$.

\section{RESULTS AND DISCUSSION \\ Genotypic and Phenotypic Coefficient of Variation (GCV and PCV)}

Information on variability and heritable components is essential to plant breeder for deciding a future breeding procedure. High estimates of GCV and PCV was recorded for seed yield per plant, 100-seed weight, biological yield per plant and harvest index per plant in RILs. Among RILs the variation in yield potential depends upon number of pods, seeds per plant and 100-seed weight. Variation in biological yield per plant depends upon plant growth habit and period of vegetative phase. It is important to mention that variation in maturity period in $\mathrm{P}_{1}$ (ICC 283) and $\mathrm{P}_{2}$ (ICC 8261) was 9 days, whereas in RILs it was 107 to 131 days. The range of maturity duration did not vary as was expected. Low variation was also evidenced by low values of PCV and GCV for days to maturity. The range of variation for days to $50 \%$ flowering in RILs was quite wide as compared to maturity duration. The range of days to $50 \%$ flowering varied from 42 to 93 days in RILs. It was found that the high range of variation in days to $50 \%$ flowering was associated with different plant growth habits recorded in RILs. The RILs possessing prostrate plant growth habit started flowering very late as compared to those RILs having spreading, semi-spreading and semi-erect plant growth habit. Prostrate growth habit is predominantly observed in wild species and are not suitable for commercial exploitation in chickpea improvement. The high variation in flowering period provides better scope for selection of late and early flowering RILs. 
Early flowering and late maturity facilitate long reproductive period and long seed setting period, hence early flowering with late maturity is considered as desirable for yield improvement in chickpea. Duration of reproductive period is also important criteria for realizing high yields ${ }^{8}$. It is reported that 50 55 days reproductive period is optimum for good seed setting. Therefore, early flowering coupled with optimum duration of reproductive period is important for increasing higher yields. In this investigation high GCV and PCV was recorded for seed yield per plant, biological yield per plant, harvest index per plant and 100-seed weight, whereas days to $50 \%$ flowering, days to maturity and plant height showed moderate to low variability. The proportion of heritable variation evidenced by the magnitude of GCV and PCV values was relatively high in respect of seed weight compared to that of pods per plant and seed yield per plant ${ }^{9}$. Narrow PCV was recorded by ${ }^{10,11}$ in chickpea germplasm. Sidramappa ${ }^{12}$ also reported GCV and PCV in RILs' population of chickpea derived from a cross between ICCV 2 x JG 62, they reported $\mathrm{GCV}$ and PCV for days to $50 \%$ flowering were slightly lower as compared to present investigation. They also reported the PCV values which were slightly higher than GCV values for plant height, number of branches/plant, days to first flowering, days to $50 \%$ flowering, days to pod initiation, days to physiological maturity, duration of reproductive phase, number of pods/plant, 100-seed weight and seed yield/plant indicating very low influence of environment in the expression of these traits. The proportion of heritable variation is evidenced by the magnitude of GCV and PCV values. The PCV and GCV values were relatively high for seed weight as compared to pods per plant and seed yield per plant ${ }^{9}$. Sharma ${ }^{13}$ observed high GCV for seed yield, 100-seed weight, plant population per $\mathrm{m}^{2}$, number of secondary branches per plant, number of pods per plant, number of grains per plant, plant height and days to flowering. High GCV for these traits suggested a good scope of chickpea crop improvement.

\section{Heritability}

Heritability is the heritable portion of phenotypic variance. It is a useful index of the transmission of characters from parents to their offspring $^{14}$. Heritability is a measure of the contribution of the genotypes to the total variation. It provides the relationship between the genotypic and phenotypic variance and indicates the degree to show that to what extent the characters of the individuals are inherited to the offspring. When the heritability estimates of qualitative and quantitative traits are high (i.e. more than $60 \%$ ), the phenotypic appearance would provide a close measure of genotypic value and selection on the basis of phenotypic performance alone may be effective. If the heritability is low (i.e. less than 30\%), the environmental influence are high in the expression of these traits which ultimately necessitates progeny testing for assessing the true breeding value of characters. Selection based on particular character will be effective when its heritability estimate is high. Burton ${ }^{5}$ suggested that GCV together with heritability estimates would give the best picture of the extent of advance to be expected by selection. In the present investigation, high estimates of heritability in broad sense were observed for days to $50 \%$ flowering, days to maturity, plant height, biological yield per plant, seed yield per plant, harvest index per plant and 100-seed weight studied. This result indicates that these characters were highly heritable and hence were less affected by the environment. The plant breeder therefore may use these characters for selection on the basis of phenotypic expression in the individual RIL. Mathur and Mathur $^{15}$ estimated high heritability for plant height, days to flowering, days to maturity, pods per plant, grain yield per plant and thousand grain weight in chickpea. Sidramappa ${ }^{12}$ observed high heritability along with high variation for pods per plant, seed yield per plant, 100-seed weight, days to $50 \%$ flowering, days to pod initiation and plant height compared to other traits. The findings of present study are in accordance with the results of ${ }^{16}$ as their 
findings also showed high heritability with high variation for pods per plant, seed yield per plant, 100-seed weight, days to $50 \%$ flowering, days to pod initiation and plant height. Chauhan ${ }^{10}$ reported genetic variability was highest for pods per plant, flower initiation and number of primary and secondary branches per plant.

\section{Genetic Advance}

The genetic gain that can be expected by selection for a character was estimated by genetic advance. A relative comparison of heritability estimates and expected genetic advance will give an idea about the nature of gene action governing a particular character. A comparison of these two estimates made in this study revealed that seed yield per plant, biological yield per plant, harvest index per plant and 100-seed weight had high heritability estimates coupled with high genetic advance as percentage of mean suggesting that these characters are under the control of additive gene action and potential possibilities exist for the improvement of these traits through simple selection. Moderate genetic advance as percentage of mean for days to $50 \%$ flowering and plant height was due to low genetic variability for these traits. Present research findings also showed agreement with the outcome cited by various scientists. The high genetic advance expressed in percent of mean was recorded in the present study for seed yield per plant followed by 100 -seed weight, biological yield per plant and harvest index per plant are in agreement of the findings of ${ }^{12}$. Moderate genetic advance was observed for days to $50 \%$ flowering and plant height. These findings of moderate genetic advance for days to $50 \%$ flowering were also obtained by ${ }^{12,17}$. Ali 18,12 reported that seed yield per plant, number of pods per plant and 100-seed weight had high heritability estimates coupled with high genetic advance. High heritability coupled with low genetic advance for 100-seed weight was also reported by ${ }^{19,20}$, and for seed yield per plant reported by ${ }^{21,22,23}$. Plant height had high heritability was also reported by ${ }^{24,10}$. High heritability coupled with high genetic advance was observed for biological yield per plant, seed yield per plant, harvest index and 100 -seed weight in this investigation that indicated that additive gene played a major role for inheritance of these traits and these traits were least influenced by environmental effects. Low genetic advance was recorded for days to maturity. High heritability was associated with low genetic advance for days to maturity that indicated presence of dominant gene for the control to maturity duration. Qureshi ${ }^{25}$ reported high heritability with low genetic advance of days to $50 \%$ flowering, days to maturity and 100-seed weight indicated the influence of dominant and epistatic genes for these traits and high heritability for biological yield coupled with high genetic advance suggest that additive gene effects are important in determining these characters. Sharma ${ }^{13}$ recorded high heritability for 100-seed weight, days to flowering, days to maturity, plant height, which indicated heritable portion of the variability. High heritability was associated with high genetic advance as percent of mean for plant height, days to flowering and 100-seed weight ${ }^{10,26}$.

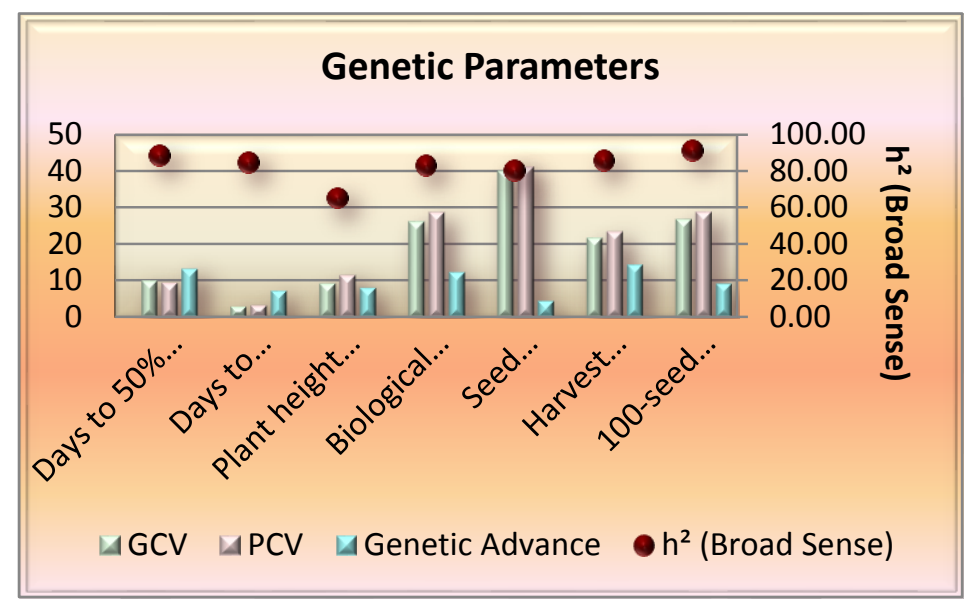

Fig. 1: Different values of genetic parameters in RILs \& parents 
Table 1: GCV, PCV, $\mathrm{h}^{2}$ and Genetic advance as percentage of mean for yield and yield attributes in RILs and parents

\begin{tabular}{|c|c|c|c|c|c|c|c|}
\hline $\begin{array}{c}\text { Traits } \\
\text { Genetic parameters }\end{array}$ & $\begin{array}{c}\text { Days to } \\
50 \% \\
\text { flowering }\end{array}$ & $\begin{array}{l}\text { Days to } \\
\text { maturity }\end{array}$ & $\begin{array}{l}\text { Plant } \\
\text { height } \\
(\mathrm{cm})\end{array}$ & $\begin{array}{c}\text { Biological } \\
\text { yield/ plant } \\
\text { (g) }\end{array}$ & $\begin{array}{l}\text { Seed yield/ } \\
\text { plant (g) }\end{array}$ & $\begin{array}{c}\text { Harvest } \\
\text { index/ } \\
\text { plant }(\%)\end{array}$ & $\begin{array}{c}100 \text {-seed } \\
\text { weight (g) }\end{array}$ \\
\hline $\begin{array}{l}\text { Phenotypic coefficient of } \\
\text { variation }(\mathrm{PCV})(\%)\end{array}$ & $9.6(\mathrm{~L})$ & $3.4(\mathrm{~L})$ & $11.6(\mathrm{M})$ & $28.8(\mathrm{H})$ & $41.1(\mathrm{H})$ & $23.5(\mathrm{H})$ & $28.9(\mathrm{H})$ \\
\hline Heritability $\left(\mathrm{h}^{2}\right)(\%)$ & $88.3(\mathrm{H})$ & $84.7(\mathrm{H})$ & $65.3(\mathrm{H})$ & $83.1(\mathrm{H})$ & $80.6(\mathrm{H})$ & $85.6(\mathrm{H})$ & $91.5(\mathrm{H})$ \\
\hline $\begin{array}{l}\text { Genetic advance } \\
(\mathrm{GA})(\%)\end{array}$ & 13.3 & 7.3 & 8.1 & 12.3 & 4.6 & 14.4 & 9.3 \\
\hline \multirow[t]{2}{*}{ Range } & 42 & 107 & 28.20 & 7.91 & 2.14 & 11.65 & 6.30 \\
\hline & 93 & 131 & 54.15 & 39.69 & 17.49 & 48.60 & 34.35 \\
\hline
\end{tabular}

\section{CONCLUSION}

Out of seven characters studied biological yield per plant, seed yield per plant, harvest index and 100-seed weight exhibited high GCV and heritability coupled with high genetic advance as percent of mean which revealed that these traits might be under control of additive gene effects and therefore these traits are more reliable for effective selection for developing desirable lines.

\section{Acknowledgements}

Authors are highly thankful to Dr. P.M. Gaur, Principal Scientist, Chickpea Breeding \& Theme Leader Crop Improvement, ICRISAT, Patancheru, Telangana, India for providing the experimental material for conducting research.

\section{REFERENCES}

1. Kim, D.H., Kaashyap, M., Rathore, A., Das, R.R., Parupalli, S., Upadhyaya, H.D., Gopalakrishnan, S., Gaur, P.M., Singh, S., Kaur, J., Yasin, M., Varshney, R.K., Phylogenetic diversity of Mesorhizobium in chickpea. J. Biosci. 39: 1-5 (2014).

2. Doebley J.F., Gaut B.S. and Smith B.D., The molecular genetics of crop domestication. Cell 127:1309-1321 (2006).

3. Lenser $\mathrm{T}$ and Theissen G., Molecular mechanisms involved in convergent crop domestication. Trends Plant Sci. doi: 10.1016/j.tplants (2013).

4. Olsen, K.M. and Wendel, J.F., A bountiful harvest: genomic insights into crop domestication phenotypes. Annu. Rev. Plant Biol. 64: 47-70 (2013).

5. Burton, G.N., Quantitative inheritance in the interpretation of numerical plantation data. Newzealand J., 54(6): 3-59 (1952).

6. Burton, G.W. and Devane, E.M., Estimating heritability in tall Fescue (Festuca arunidinacea) from replicated clonal material. Agron. J. 45: 478-481 (1953).

7. Johnson, H.W., Robinson, H.F. and Comstock, R.E., Estimation of genetic and environmental variability in soybean. Agron. J. 47: 477-483 (1955).

8. Sidramappa, Relationship of phenological traits with productivity in chickpea (Cicer arietinum L.). M.Sc. (Agri.) Thesis, Univ. Agric. Sci., Dharwad (India) (2003).

9. Jeena, A.S. and Arora, P.P., Role of variability for improvement in chickpea. Legume Res., 24(2): 135-136 (2001).

10. Chauhan, V.W., Patil, H.S. and Rasal, P.N., Genetic variability, correlation studies and their application in selection of high yielding genotypes of chickpea. Madras. J. Agri., 81(9): 463-465 (1994). 
11. Vijayalakshmi, N.V.S., Kumar, Jagdish, Rao, T.N. and Kumar, J., Variability and correlation studies in Desi, Kabuli and intermediate chickpea. Legume Res., 23(4): pp 232-236 (2000).

12. Sidramappa, S., Patil, S.A., Salimath, P.M. and Kajjidoni, S.T., Genetic variation for productivity and its related traits in a recombinant inbred lines population of chickpea. Karnataka J. Agric. Sci., 21(4): 488-490 (2008).

13. Sharma, D.J., Bhandarkar, S., Sharma, D.K. and Thakur, B.S., Studies on genetic variability and correlation analysis in chickpea. In proceedings of International conference on chickpea research for the millennium center Raipur, India, pp 93-94 (2003).

14. Falconer, D.S., Introduction to Quantitative Genetics. Longman, New York (1960).

15. Mathur, R. and Mathur, M.L., Estimation of genetic parameters and interrelationship of quantitative traits in chickpea. Madras Agric. J., 83(1): 9-11 (1996).

16. Samal, K.M., Jagdeo, P.M. and Lenka, D., Genetic divergence in chickpea. International chickpea Newsletter, 21: 5-6 (1989).

17. Arora, P.P. and Jeena, A. S., Genetic variability studies in chickpea. Legume Res., 24(2): 137-138 (2001).

18. Ali, M.A., Nausherwan Nobel Nawab, Ghulam Rasool and Muhammad Saleem. Estimates of variability and correlations for quantitative traits in Cicer arietinum. Journal of Agriculture \& Social Sciences, 04: 177-179 (2008).
19. Mandal, A.K. and Bahl, P.N., Estimate of variability and genetic correlation in chickpea. Annual Agric. 1(2): 136-140 (1980).

20. Agrawal, A.P., Patil, S.A. and Math, P.M.S., Studied genetic variability of some characters over the season in soybean, Madras Agriculture Journal, 88(1/3): 3640 (2001).

21. Mishra, Rajesh, Rao, G.K. and Koutu, G.K., Genetic variability, correlation studies and their application in selection of high yielding genotype of chickpea. Indian J. Agric. Res., 22(1): 51-57 (1988).

22. Anil Kumar, T.V., Salimath, P.M., Parameshwarappa, R., Chetti, M.B. and Patil, S.S., Genetic diversity on the basis of photosynthetic and yield related traits in chickpea. Indian J. Genet., 53(3): 279-286 (1993).

23. Jahagirdar, J.E., Patil, R.A. and Khare, P.R., Genetic variability and its relevance in chickpea improvement. Indian J. Pulses Res., 7(2): 179-180 (1994).

24. Sharma, B.D., Sood, B.C. and Malhotra, V.V., Studies on variability, heritability and genetic advance in chickpea. Indian $J$. Pulses Res., 3: 1-6 (1990).

25. Qureshi, Afsari Sharif, Shaukat, Anila, Bakhshi, A., Arshad M. and Ghafoor A., An assessment of variability for economically important traits in chickpea (Cicer arietinum L.) Pak. J. Bot., 36(4): 779-785 (2004).

26. Kumar, S., Arora, P.P. and Jeena, A.S., Genetic variability studies for qualitative traits in chickpea. Agril. Sci. Digest., 21(4): 263-264 (2001). 